\title{
Difficulties in translating Russian classics: Pushkin's novel “Eugene Onegin” in English and French
}

\author{
Elena N. REMCHUKOVA and Ekaterina M. NEDOPEKINA \\ Peoples' Friendship University of Russia (RUDN University) \\ Moscow, Russia
}

\begin{abstract}
A translator of classical literature is faced with the task of identifying the goal and methods of conveying the national originality of a generally recognized literary masterpiece. The article considers this problem in the context of translations of the novel in verse Eugene Onegin by Alexander Pushkin into English and French. At the same time, it raises the questions of the translators' attitude to their own work, the depth of interpretation of the original, the degree of adaptation of the original text for a foreign reader. In addition, a matter of great importance is the translators' assessment of the result of their own work, which is reflected in their comments and preface to the translated text. The goal of this research is to substantiate the importance of the linguistic and cultural function of comments and prefaces, which also made it possible to identify the features of the translations themselves and emphasize their continuity. When translating works of classical literature, translators do not limit their task to the translation itself. In this regard, the "preface-commentary" complex is viewed in the article as an important part of the translator's work. The research material includes about 40 English and over 10 French translations made in the 19th, 20 th and 21 st centuries and presented in chronological order. Mainly those that are accompanied by prefaces and comments were selected for the analysis. The research helps to present the translations of the novel not only in terms of continuity, but also in terms of their authors' critical attitude to each other, thus bringing these components of translation into the focus of a professional discussion. As a result of comparing various translations, it is possible to identify the difficulties of literary translation of the novel Eugene Onegin, which include the preservation of its poetic form, the panoramic nature of its composition, including scenes of life of the 19th century Russian nobility, and the national spirit associated with the translation of national and cultural vocabulary. The research confirms that the very fact of numerous translations of this novel, which is paradigmatic for the Russian culture, can be viewed as a form of its worldwide recognition, regardless of the professional and reader's assessment of these translations. This enables us to speak of the existence of a strong tradition that has developed in European translation studies around this particular work. Keywords: Eugene Onegin, literary translation, translation activity, prefaces and comments, intercultural communication, translation studies
\end{abstract}

\section{For citation:}

Remchukova, Elena N. \& Nedopekina, Ekaterina M. 2020. Difficulties in translating Russian classics: Pushkin's novel "Eugene Onegin" in English and French. Russian Journal of Linguistics 24 (4). 945-968. DOI: 10.22363/2687-0088-2020-24-4-945-968 
Научная статья

\title{
Трудности перевода русской классики: роман А.С. Пушкина «Евгений Онегин» на английском и французском языках
}

\author{
Е.Н. РЕМЧУКОВА, Е.М. НЕДОПЁКИНА \\ Российский университет дружбы народов \\ Москва, Россия
}

\begin{abstract}
Аннотация
При переводе текста классической литературы перед переводчиком встает задача определения цели и способов передачи национального своеобразия общепризнанного литературного шедевра. Эта проблема рассматривается в статье в контексте переводов на английский и французский языки романа в стихах А.С. Пушкина «Евгений Онегин». Вместе с тем поднимается вопрос об отношении переводчика к собственной работе, о глубине интерпретации произведения, о степени адаптации оригинального текста для иностранного читателя. Кроме того, важное значение имеет оценка автором перевода результата своего труда, которая находит выражение в сделанных им комментариях и предисловии к переводному тексту. Целью данного исследования стало обоснование важности лингвокультурной функции комментариев и предисловий, что позволило также выявить особенности самих переводов и подчеркнуть их преемственность. При переводе национально значимых произведений классической литературы задача переводчика может не исчерпываться собственно переводом. В связи с этим комплекс «предисловие-комментарий» рассматривается в статье как важная часть переводческой деятельности. Материалом исследования послужили переводы XIX, XX и XXI веков (около 40 английских и более 10 французских), представленные в хронологической последовательности. Для анализа в основном были выбраны те из них, которые сопровождаются предисловиями и комментариями. Проведенное исследование позволяет представить переводы романа не только в аспекте преемственности, но и в аспекте критического отношения их авторов друг к другу, что придает этим составляющим переводческой деятельности характер профессиональной дискуссии. В результате сопоставления разных переводов удалось выявить трудности художественного перевода романа «Евгений Онегин», к которым относятся сохранение его стихотворной формы, панорамности его композиции, включающей картины жизни русского дворянства XIX века, и национального колорита, связанного с переводом национально-культурной лексики. Исследование подтвердило, что сам факт многочисленных переводов хрестоматийного для русской культуры романа (независимо от их профессиональной и читательской оценки) можно рассматривать как форму его мирового признания, что позволяет говорить о существовании прочной традиции, сложившейся в европейском переводоведении именно вокруг этого произведения.
\end{abstract}

Ключевые слова: «Евгений Онегин», художественный перевод, переводческая деятельность, предисловия и комментарии, межкультурная коммуникация, переводоведение.

\section{Для цитирования:}

Ремчукова Е.Н. Недопёкина Е.М. Трудности перевода русской классики: роман A.C. Пушкина «Евгений Онегин» на английском и французском языках. Russian Journal of Linguistics. 2020. T. 24. № 4. C. 945-968. DOI: 10.22363/2687-0088-2020-24-4-945-968

\section{1. Введение}

Проблема перевода на иностранные языки национальных шедевров литературы той или иной страны является, с одной стороны, проблемой 
классической, традиционной, с другой, безусловно, актуальной. Сохраняя константу национального достояния, литературный шедевр продолжает жить и как актуальное литературное произведение. В связи с этим возникают важные вопросы. Главный из них - вопрос о самой необходимости новых переводов, противопоставленных более ранним, или, напротив, «созвучных» им. Но и те, и другие отражают очередную попытку «улучшения» перевода не только в рамках заданной стилистики времени, но и с позиций пиетета переводчика перед национальным шедевром. Кроме этой общей проблемы, касающейся перевода практически любого признанного художественного творения, существует комплекс проблем, связанных с трансляцией на другие языки такого уникального произведения русской литературы первой трети XIX века (1823-1830), каким является роман А.С. Пушкина «Евгений Онегин».

Попытка проанализировать в данной статье французские и английские переводы этого романа в комплексе с предисловиями и комментариями к ним позволяет выявить:

1) общие закономерности, характерные для всех переводов этого романа на протяжении более чем двух веков, обусловленные его национальным колоритом и художественным своеобразием;

2) индивидуальные особенности отдельных переводов, отражающие личные пристрастия переводчиков, так как художественный перевод всегда выходит из «творческой лаборатории» конкретного человека;

3) основные трудности межъязыкового перевода, обусловленные своеобразием содержания, формы и жанра данного произведения.

Своеобразие «Евгения Онегина» обусловлено его принадлежностью символу русской культуры - А.С. Пушкину. Написанный в соответствии с западноевропейской литературной традиции начала XIX века, роман мог восприниматься европейским читателем того времени как «вторичный», однако он обладает ярким национальным своеобразием и по праву считается «энциклопедией русской жизни» (В.Г. Белинский). Кроме того, жанр романа в стихах делает его перевод еще более сложным. На этих особенностях мы остановимся подробнее ниже (см. 2.1).

Цель анализа, предложенного в статье, обусловлена необходимостью подчеркнуть (на фоне социально-исторических трансформаций сегодняшнего дня), что творчество А.С. Пушкина, безусловно, является фактом не только русской, но и европейской культуры, о чем свидетельствует устойчивый интерес к новым переводам его произведений уже в XXI веке. Этому способствуют традиционные культурные связи между Россией и Европой, которые, к счастью, остаются за скобками современных политических реалий. В развитии этих связей на новом историческом витке интерес к русской литературе - как современной, так и классической - играет важнейшую роль.

Поставленной целью обусловлен круг задач, требующих решения в рамках данной статьи: представить переводы романа на английский и французский языки в аспекте хронологической последовательности; описать 
их языковую динамику с точки зрения как формы (стихотворной или прозаической), так и содержания; обосновать важность лингвокультурной функции комментариев переводчика и актуальность самого обращения к классическому произведению с точки зрения решения задач межкультурной коммуникации и переводоведения. Одной из таких задач является изучение лингвистических особенностей переводов XXI века с точки зрения культурной адаптации на основе их сопоставления с переводами предшествующих веков. Отметим, что за пределами данной статьи остается важное для нас направление - лингвистический анализ конкретных переводов романа разных периодов. Такие исследования проводятся на материале английских (Нестерова 2014, 2017, Панченко 2011) и французских переводов (Богинская 2016).

Материалом исследования послужили переводы романа А.С. Пушкина на английский и французский языки, сделанные в течение более 150 лет, однако для сопоставительного анализа были выбраны в основном те из них, которые в соответствии с поставленными в статье задачами сопровождаются предисловиями, комментариями или комплексом «предисловие-комментарий». Анализируются переводы, принадлежащие иноязычным авторам: среди них английские - Г. Сполдинга, Ч. Джонстона и С. Митчелла и французские Л. Виардо (совместно с И.С. Тургеневым), П. Безо, А. Марковича. Исключением является перевод выдающегося русского писателя В.В. Набокова, который широко известен и как англоязычный автор (этот перевод сопровожден самыми объемными и детальными комментариями к роману).

Наряду с общими методами синтеза и анализа, применяемыми в процессе изучения любого художественного текста, в данном исследовании используется ряд специальных методов. Среди них сопоставительный метод, который позволяет сравнить оригинальный текст и упоминаемые в этой работе его переводы на английский и французский языки. Интерпретационный метод используется для трактовки предисловий и комментариев, сделанных авторами переводов; с помощью количественного анализа стало возможным определить количество переводов «Евгения Онегина» на английский и французский языки; диахронический подход к исследованию переводов романа позволил проследить их историю. Наконец, лингвокультурологический метод позволил выявить некоторые национальные особенности оригинального текста в аспекте перевода, обнаружить глубокие непреодолимые противоречия между оригиналом и переводным текстом, в которых опосредованно проявляется связь между языком и мышлением и связь между индивидуальным подходом переводчика и масштабом этого уникального произведения.

Теоретическую базу исследования составили статьи о художественных переводах (Behr \& Sha 2018, Dam-Jensen 2020, Loupaki 2017), работы по переводоведению (Сдобников 2019) и о переводах русской классики (например, Чеснокова, Талавера-Ибарра 2015), классические статьи о языке А.С. Пушкина (Виноградов 1999 и др.), статьи о влиянии французского языка на язык А.С. Пушкина (Гак 2002), статьи о переводах романа А.С. Пушкина 
«Евгений Онегин» (Danilova 2020, Нестерова 2014, 2017, Razymnaya 2020, Razumovskaya 2011, Эткинд 1999), в частности, отдельные работы по переводу и комментариям В.В. Набокова (Kobrina-Coolidge 2015), комментарии к роману «Евгений Онегин» (Набоков 1999, Лотман 1983), а также некоторые исследования, связанные с лингвистическим анализом параллельных текстов (Богинская 2016, Панченко 2011).

Данное исследование находится в русле переводоведения, которое решает задачи «как традиционных видов перевода (художественный перевод, религиозный перевод, устный перевод), так и относительно новых видов переводческой деятельности (аудиовизуальный перевод, локализация)» (Сдобников 2019: 296). Размышляя о задачах переводоведения, В.В. Сдобников разделяет собственно перевод как главный элемент деятельности переводчика и переводческую деятельность. Последняя «предполагает культурную адаптацию текста к восприятию получателей перевода» (там же). Одной из форм этой «культурной адаптации» и являются авторские предисловия и комментарии, которые сопровождают перевод. В тех случаях, когда речь идет о таких произведениях классический литературы, как роман «Евгений Онегин», эта адаптация принимает разные формы - от кратких замечаний по поводу специфики национального быта и единиц русского языка до глубокого лингвистического погружения не только в реалии русской жизни, но и в язык (как оригинала, так и перевода), которое мы обнаруживаем в комментариях В. Набокова.

\section{2. Результаты исследования}

\section{1. Своеобразие романа в аспекте формы и содержания и трудности его перевода}

Роман «Евгений Онегин» занимает совершенно особое место в истории русской литературы и культуры в целом, однако степень этой значимости не вполне очевидна европейскому читателю и, возможно, даже переводчику. Остановимся на тех особенностях, которые определяют его уникальность, а также выявим возможные противоречия в восприятии романа европейскими переводчиками.

1. Роман принадлежит перу русского гения: А.С. Пушкин является символом не только русской литературы, но и всей русской культуры, фигурой, равной в этом смысле фигурам Данте, Шекспира, Гёте, Байрона и других европейских гениев, символизирующих собой вершины национальных достижений.

2. Классическое пушкиноведение считает роман главным пушкинским творением. Он входит в обязательную программу по литературе для общеобразовательных школ, отдельные фрагменты этого текста школьники заучивают наизусть, что обеспечивает его закрепление в русском языковом сознании. 
3. Роман является широко цитируемым текстом, он востребован, в том числе и в современном рекламном дискурсе, как прецедентный текст, и это не единичные случаи, а устойчивая традиция. Название романа используется, например, в номинации одной из разновидностей популярного чая «Майский», который так и называется «Чай Майский Пушкин. Евгений Онегин (Чай Майский в популярном подарочном формате "Книга")» ${ }^{1}$. Строки из текста романа звучат в телерекламе чая этой же торговой марки ${ }^{2}$. Дискуссия по поводу того, насколько уместно подобное использование символов национальной культуры, остается за рамками данной статьи, но сам этот факт свидетельствует о том, что «Евгений Онегин» занял прочное место в массовой культуре и коммуникации.

4. Роман соединяет гениальность формы и содержания, что всегда отмечалось русской критикой начиная с XIX века (в первую очередь В.Г. Белинским), преимущественно восторженной на протяжении двух веков. Роман критиковали за те или иные недостатки современники (И.В. Киреевский, И.И. Надеждин, впоследствии - Д.И. Писарев); в советском литературоведении пушкиноведение как наука достигло высочайшего уровня, но отчасти носило мифологизированный характер.

5. Являясь первым русским реалистическим романом, «Евгений Онегин» имеет новаторский характер. Однако эта его черта, как и другие - историзм, народность (как отражение истинно русских характеров, реалий русской жизни и образа мыслей русского дворянства) - мало что говорят европейскому читателю, которым прежде всего является переводчик-интерпретатор: сюжет романа может показаться вторичным по отношению к английской и французской литературе конца XIII - начала XIX веков. Это касается не только основной линии сюжета, но и отсылки характеров главных героев к романтическим персонажам Дж. Байрона, а также близости женских характеров к героиням французских (например, Ж-Ж. Руссо) и английских (например, Д. Остин) сентиментальных романов. К этим произведениям в тексте романа отсылает нас и сам автор: Татьяна читает Руссо, Онегин сравнивается с Чайльд-Гарольдом. Примеры эти неоднократно описаны в классической филологической литературе (см., например, Виноградов 1999, Лотман 1983 и др.).

6. Связь романа с французской литературой и французским языком сложнее и прочнее в силу диглоссии, характерной для русского дворянского общества той эпохи. В частности, в литературе упоминаются те реминисценции из французских литературных текстов, которые встречаются в письме Татьяны. Об этом пишет, например, Ю.М. Лотман с отсылкой к Л.С. Сержану, который «высказал предположение, что основным источником письма Татьяны является элегия Марселины Деборд-Вальмор (1786-1859) - второстепенной французской поэтессы, сборник стихотворений которой вышел в

\footnotetext{
${ }^{1}$ https://priceguard.ru/offer/ozon-138191531

2 https://www.youtube.com/watch?v=6mdLIUhMXTI
} 
1819 г. и потом несколько раз переиздавался. Причину обращения П к элегии французской поэтессы исследователь видит в том, что «в этих стихах наш поэт нашел, очевидно, то, что он так ценил в творчестве А. Шенье <...> изумительную, неподдельную искренность» (Сержан 1975: 545). Текст элегии Деборд-Вальмор, действительно, имеет ряд точек соприкосновения с письмом Татьяны, позволяющих утверждать, что он был известен П и был у него на памяти во время работы над письмом» (Лотман 1983: 228). Определенную сложность в аспекте перевода романа представляет присутствие в нем значительного количества французских заимствований (реалий, слов, имен собственных), контекст употребления которых, как нам представляется, далеко не всегда понятен как русскому, так и европейскому читателю особенно современному.

7. Роман А.С. Пушкина написан привычным для русскоязычного читателя классическим стихотворным размером - четырехстопным ямбом, типичным для русской поэзии XIX века. Этот размер и уникальная, созданная Пушкиным специально для романа «онегинская строфа» (три четверостишья с определенной, строго выдержанной рифмовкой и две заключительные строфы, часто обобщающего содержания) придают уникальность и соразмерность всей конструкции, при этом, чтобы она предстала во всей гармонии, ее нужно было коснуться волшебным пером поэта. «Однако на Западе он [Пушкин] ценится менее других потому, что он наименее знаком читателям по сравнению с другими русскими авторами. Причину его невысокой известности далеко искать не надо. Главной средой его обитания является поэзия, но такая поэзия, которая в наименьшей мере поддается переводу потому, что ей недостает выражения и она наивна по мышлению, а ее магическая сила зиждется на точности, ясности и вербальном красноречии, которое настолько ощутимо, насколько и недоступно для передачи на другой язык» (Челышев 2015: 4).

Этим списком не исчерпываются все трудности при переводе произведений такого жанра, как «роман в стихах». Однако основной вопрос, который стоит перед переводчиком, можно сформулировать так: переводить роман прозой, акцентируя внимание на широте представленной в нем картины русской жизни первой трети XIX века, или попытаться передать «магию»его поэтической формы, сохранив широту повествования? И приступая к работе, переводчик должен решить, что важнее, сделав нелегкий выбор.

При этом интересно отметить, что в истории переводов «Евгения Онегина» есть случаи возвращения переводчика к оригинальному тексту в стремлении создать новую версию перевода, более точную и совершенную. Так, У. Арндт, В.В. Набоков, В. Либерсон, Ч. Джонстон, С.Н. Козлов, Р. Кларк, Е. Бонвер и М. Хобсон в разное время сделали по две редакции своих переводов. Трижды редактировала свой перевод романа А.С. Пушкина - в 1936, 1943 и 1964 годах - Бабетт Дойч (что все-таки не позволило ей избежать критики со стороны В.В. Набокова). Все три версии представляют собой 
поэтические тексты, однако сравнение переводов позволяет увидеть, что автор продолжала работать как над содержанием, так и над формой. Об этом позволяют судить уже первые 4 строки текстов:

My uncle's shown his good intentions

By falling desperately ill;

His worth is proved; of all intentions

Where will you find one better still?

(Pushkin. Eugene Onegin. Tr. Deutsch 1936)

Впоследствии строфа звучит уже иначе:

My uncle always was respected;

But his grave illness, I confess,

Is more than I could have expected:

A stroke of genius, nothing less.

(Pushkin. Eugene Onegin. Tr. Deutsch 1943; 1964)

Очевидно, что в более позднем варианте переводчику в большей степени удается передать легкость и ироничность пушкинского стиха. Неудовлетворенность переводчика результатами своего труда связана в первую очередь с тем сложным выбором, о котором мы говорили выше и который предопределен поэтической тканью «энциклопедического» романа.

\section{2. Переводы романа на английский язык}

Обратимся к предисловиям и комментариям, сделанным ко многим переводам романа «Евгений Онегин» на английский язык, что объясняется потребностью их авторов уточнить цели перевода, перечислить трудности работы, познакомить читателя с творчеством А.С. Пушкина, дать краткий обзор его биографии, рассказать о своих мотивах обращения к роману. Важной частью предисловий является критика коллег, чьи переводы были опубликованы ранее. Это связано с тем, что авторы «предвидят» свои возможные ошибки, которые неизбежны в условиях сложности поставленной задачи. Кроме того, к некоторым переводам «Евгения Онегина» сделаны комментарии, касающиеся особенностей русской культуры и быта, формы изложения, личности поэта и даже особенностей русского языка.

Познакомить англоговорящего читателя с романом в стихах А.С. Пушкина «Евгений Онегин» в разное время пробовали более 40 переводчиков: Г. Сполдинг (H. Spalding) (1881), К. Филипс-Уолли (С. Phillipps-Wolley) (1883), Б. Дойч (B. Deutsch) (первый перевод вышел в свет в 1936, а исправленные варианты были опубликованы в 1943, 1963), О. Элтон (O. Elton) (1937), Д. Радин (D.P. Radin) и Дж. Патрик (G.Z. Patrick) (1937), Б. Симмонс (B. Simmons) (1950), У. Арндт (W. Arndt) (1964 и исправленный вариант текста в 1992), Е. Кайден (Е. Kayden) (1964), В.В. Набоков (1964 и повторная публикация в 1975), Дж. Хардинг (J.Harding) (1967), В. Либерсон (W. Liberson) (1975 и исправленный вариант в 1987), Ч. Джонстон 
(Ch. Johnston) (1977 и вторая публикация в 2003), С.Д.П. Кло (S.D.P. Clough) (1988), С.Н. Козлов (1994 и еще один вариант в 1998), Дж. Фален (J.E. Falen) (1995), М. Шерер (М. Sharer) (1996), К. Кайл (С. Cahill) (1999), Р. Кларк (R. Clarke) (1999 и переизданный перевод 2011), Э. Корр (А. Corre) (1999), Д. Хофштадтер (D.R. Hofstadter) (1999), О. Эммет (O. Emmet) и C. Макуренкова (1999), Дж. Леджер (G.R. Ledger) (2001), Д. Литошик (D. Litoshick) (2001), Т. Бек (Т. Beck) (2004), Е. Бонвер (Е.Y. Bonver) (2004 и переизданный перевод 2005), М. Стоун (M.K. Stone) (2005), Г. Хойт (Н. Hoyt) (2008), C. Митчелл (S. Mitchell) (2008), Э. Клайн (A. Kline) (2009), Дж. Лоуэфельд (J.H. Lowenfeld) (2010), Д. Томас (J.D. Thomas) (2011), М. Хобсон (M. Hobson) (публикации 2011 и 2016), Э. Бриггс (A. Briggs) (2016), Н. Потной (N. Portnoi) (2016). Важно обратить внимание на хронологию переводов: первый перевод романа на английский язык сделан в XIX веке, спустя 44 года после смерти А.С. Пушкина, в 1881 году, Генри Сполдингом (Henry Spalding). Отметим также, что это одна из первых попыток перевода пушкинского текста с сохранением уникальной онегинской строфы.

В предисловии к переводу Г. Сполдинг пишет: «Tastes are various in matters of poetry, but the present work possesses a more solid claim to attention in the series of faithful pictures it offers of Russian life and manners» [Что касается поэзии, вкусы различны, но данная работа заслуживает значительного внимания в том, что касается правдивых картин, изображающих русскую жизнь и привычки ${ }^{3}$ (Pushkin. Eugene Onegin. Tr. Spalding 1881). Таким образом, переводчик, оценивая свои усилия, считает, что ему в целом удалось описание русского быта, даже если он не вполне справился со сложной стихотворной формой. Отмечая, что в романе ощущается влияние творчества великого английского поэта Дж. Байрона, Г. Сполдинг признает, что сохранение оригинальной строфики романа представляет собой значительную сложность не только для переводчика, но и для читателя: «I must plead in excuse the difficult form of the stanza» [Я прошу прощения за сложность формы стиха] (ibid).

Кроме того, он отмечает, что переводить оригинальный текст особенно трудно тогда, когда он содержит элементы диалога, живой речи и описание местных обычаев: «In the "notes" I have endeavored to elucidate a somewhat obscure subject. Some of the poet's allusions remain enigmatical to the present day» [В «примечаниях» я постарался пояснить некоторые непонятные явления. Однако некоторые из указаний поэта остаются загадкой и сегодня] (ibid). Это замечание Г. Сполдинга, сделанное в 1881 году, особенно актуально и теперь в условиях интенсивного развития межкультурной коммуникации как науки, так как перевод литературного произведения - это всегда интерпретация национального содержания для иностранного читателя.

С этой целью Г. Сполдинг делает 86 исторических, культурных и литературных комментариев к роману. Например, в комментарии 70 он отмечает слово matushka (глава VII строфа XXVI) в разговоре провинциальных соседей

\footnotetext{
3 Здесь и далее представленный в квадратных скобках перевод сделан авторами статьи.
} 
с матерью Татьяны, которые советуют ей отвезти дочь в Москву на ярмарку невест, обращаясь к ней «матушка» (Я думала: пойдет авось; /Куда! и снова дело врозь. / «Что ж, матушка? за чем же стало? / В Москву, на ярманку невест! / Там, сльишно, много праздных мест». / - Ох, мой отец! доходу мало. / - «Довольно для одной зимыл...» (Пушкин 1978: 130). Г. Сполдинг пишет: "“matushka" or "little mother," a term of endearment in constant use amongst Russian females» ["Матушка" - ласковое слово, постоянно употребляемое среди русских женщин] (ibid). Комментарий Г. Сполдинга минимален, он не говорит о стилистической окраске слова и не поясняет, что, являясь простонародным, в дворянской среде оно использовалось в качестве обращения с оттенком фамильярности (предполагало обращение на «ты») и мужчинами, на что указывает контекст $(O x$, мой отец! доходу мало...).

Однако также приемлемым решением представляется сохранение образа русского слова, не поддающегося переводу, в транслитерации, но с английским окончанием множественного числа (см. у Г. Сполдинга kibitkas глава VII строфа XXIX); так же данная лексема представлена в переводе В.В. Набокова. Отметим, что таким образом вводится в текст перевода национально-культурная лексика у многих переводчиков романа (matushka, Samovar, troika, aboze, isba, vosok и др.).

Однако это не означает, что данная практика не знает исключений. Так, например, у Ч. Джонстона слово кибитки («кибитка» - крытый экипаж, повозка ${ }^{4}$ ) переведено как carts («телега, подвода, повозка»), а во французском переводе романа, сделанном П. Безо, - как charrettes («телега, воз»), что вполне соответствует общему контексту данной строфы (глава VII, строфа XXXI), в которой средства передвижения (кибитка, обоз, возок) играют важную роль как реалии русского быта (Отъезда день давно просрочен, / Проходит и последний срок. / Осмотрен, вновь обит, упрочен / Забвенью брошенный возок. / Обоз обычный, три кибитки / Везут домашние пожитки, / Кастрюльки, стулья, сундуки ...) (Пушкин 1978: 132).

В конце предисловия Г. Сполдинг оценивает свой труд так: «I think I may say that I have adhered closely to the text of the original» [Думаю, я могу сказать, что сумел близко передать оригинальный текст] (ibid). Переводчик признается, что опустил те лирические отступления, которые относятся к воспоминаниям поэта, потому что «memoirs do not usually excite much interest till the subjects of them are pretty well known» [мемуары обычно не вызывают интереса, пока свежа память об их предмете] (ibid). Очевидно, что Г. Сполдинг стремился адаптировать роман для восприятия современного ему читателю.

За сохранение онегинской строфы переводчик «Евгения Онегина» на английский язык Уолтер Арндт (Walter Arndt) в 1964 году был удостоен престижной Боллингенской премии, присуждаемой за особые достижения именно в области поэзии.

\footnotetext{
4 Здесь и далее значения слов даны по словарю С.И. Ожегова (Ожегов 1997).
} 
Онегинскую строфу сохраняет и перевод Чарлза Джонстона (Charles H. Johnston), сделанный в 1977 году. В предисловии переводчик оценивает недостатки более ранних переводов: «Few foreign masterpieces can have suffered more than «Eugene Onegin» from the English translator's failure to convey anything more than - at best - the literal meaning» [Немногие зарубежные шедевры могли пострадать больше «Евгения Онегина» от неспособности английского переводчика передать что-то большее, чем в лучшем случае буквальное значение] (Pushkin. Eugene Onegin. Tr. Johnston 1977). В свою очередь сам Ч. Джонстон ставит форму выше содержания и видит именно в ней ценность произведения, а также говорит о сложности ее передачи на английский язык: «It is as if a sound-proof wall separated Pushkin's poetic novel from the English-reading world» [Как будто звукоизоляционная стена отделяла пушкинский поэтический роман от англоязычного мира] (ibid). С этой точки зрения Ч. Джонстон критикует перевод В.В. Набокова, который сделал акцент на передаче содержания романа: «Vladimir Nabokov's rendering into unrhymed iambics reproduces the exact meaning, but explicitly disclaims any further ambition...It can however certainly strive for something else» [Перевод Владимира Набокова в безритмовую ямбику воспроизводит точный смысл, но явно отвергает любые дальнейшие амбиции... Однако, безусловно, следует стремиться к чему-то еще] (ibid).

Многие исследователи, в частности Е.П. Челышев и А.А. Липгарт, среди лучших переводов романа на английский язык особо выделяют перевод Дж.Э. Фалена: «В Англии и США предпринималось десять попыток перевести «Евгения Онегина»; далеко не все они оказались удачными. Лишь «применительно к нескольким текстам - в частности, к включенному в настоящий сборник переводу Дж.Э. Фалена (1996), - можно сказать, что эти попытки увенчались успехом» (Липгарт 1999: 17, цит. по Челышев 2015). Однако рядом с этим именем можно поставить фамилии других переводчиков, чьи работы специалисты по переводоведению считают успешными. Н.М. Нестерова пишет: «Именно этот перевод [Фалена] побудил Хофштадтера учить русский язык, прочитать и выучить наизусть пушкинский текст и, наконец, сделать свой перевод, который, на наш взгляд, можно поставить в один ряд с переводами Ч. Джонстона и Дж. Фалена» (Нестерова 2014). Таким образом, перевод романа Ч. Джонстоном признается специалистами одним из самых удачных.

Но нельзя сказать, что перевод В.В. Набокова является в строгом понимании этого термина прозаическим, так как он представляет собой ритмическую прозу с сохранением стихотворного размера. Однако для писателя было важно передать русский национальный колорит, поэтому он в некоторых случаях пренебрегает даже правилами английской грамматики, что отмечали многие критики и переводчики. Кроме того, В.В. Набоков сохраняет сложные для англоязычного читателя отсылки к иностранным произведениям и обилие французских слов. Поэтому этот текст отчасти может восприниматься 
английским и американским читателем как чужеродный. И в переводе, и в комментариях к роману В. Набоков стремится пояснить его сложное содержание: «...полностью манера нашего художника раскрывается в распределении сюжетного материала, равновесии частей, смене тем и отступлениях в повествовании, введении героев, отходах от основной темы, переходах и тому подобном» (Набоков 1999: 33).

Высокая степень лингвистической точности комментариев В.В. Набокова, обусловлена, как нам представляется, его безупречным владением русским (родным для него) языком. Более того, будучи выдающимся русским писателем-стилистом, он достиг таких же высот в своем творчестве на английском языке. Это становится очевидным при сопоставлении его комментариев с комментариями других переводчиков: например, Г. Сполдинг уловил оскорбительный оттенок в употреблении А.С. Пушкиным английского слова spleen по отношению к тому впечатлению, которые производят светские дамы (строфа XLII):

\section{Так величавы, так умны, \\ Так благочестия полны, \\ Так осмотрительны, так точны, \\ Так неприступны для мужчин, \\ Что вид их уж рождает сплин.}

(Пушкин 1978: 22-23)

Эта ирония вполне соответствует общей тональности многих лирических отступлений в романе. Однако переводчик сопровождает ее пространным комментарием: «The poet in all probability wrote the offending stanza in a fit of Byronic "spleen," as he would most likely himself have called it. Indeed, since Byron, poets of his school seem to assume this virtue if they have it not, and we take their utterances under its influence for what they are worth» [Однако поэт, по всей вероятности, написал оскорбительную строфу в припадке байронического «сплина», как, скорее всего, он сам бы это назвал. Действительно, со времен Байрона поэты его школы, кажется, считают добродетелью, если они не испытывают этого чувства, и мы принимаем их высказывания, понимая, чего они стоят] (Pushkin. Eugene Onegin. Tr. Spalding 1881). В то же время в предыдущей строфе он по каким-то причинам избегает перевода лексемы хандра, столь важной для характеристики русской души: «...Was nothing but the British spleen transported to our Russian clime» [...Было все лишь британским сплином, перенесенным в наш русский климат] (ibid). Сравним: у А.С. Пушкина в строфе XXXVIII: «Подобный аглицкому сплину, / Короче: русская хандра им овладела понемногу» (Пушкин 1978: 22).

В отличие от В.В. Набокова, строго следовавшего за текстом А.С. Пушкина, некоторые переводчики допускали сокращения оригинального текста, что можно проследить по несоответствию количества строф. Так, например, строфа XXXVIII у А.С. Пушкина соотносится со строфой XXXV у Г. Сполдинга, и далее этот разрыв только увеличивается. 
Созданию комментария к роману А.С. Пушкина «Евгений Онегин» В.В. Набоков посвятил девять лет. Этот комментарий уникален, потому что речь идет не просто о пояснениях к содержанию романа и разъяснениях его художественных и лингвистических особенностей. В нем представлены суждения писателя о лингвистической сущности слова - его грамматических характеристиках, лексических значениях и даже о той стилистической окраске, которая сопровождала слово, но была утрачена в процессе развития языка. Уникальность лингвистического подхода В.В. Набокова состоит в том, что он, помимо русского, в совершенстве владел английским и французским языками. Благодаря этому комментарии В.В. Набокова включают не только ономастические, лингвокультурологические и литературоведческие пометы, но и пространные лингвистические размышления, представляющие отдельную научную ценность.

По поводу некоторых слов он создает целые лингвистические сюжеты: например, для пояснения слов сплин, хандра, скука и тоска (Набоков 1999), В.В. Набоков дает соответствующие переводы не только на английский, но и на французский язык (maladie imaginaire, hypohondrie). Привлекая данные трех языков (английского, французского и русского), В.В. Набоков делает сопоставительный анализ значений лексем хандра, сплин, гипохондрия, меланхолия, скука. В результате этого сопоставительного анализа он приходит к выводу, что французское епnиi из La Grande Encyclopédie 1885 года «...верно для гипохондрических настроений всех вымышленных персонажей онегинского духа» (ibid), и далее отмечает, что «...вокабуляр, обслуживающий еппиі, включает также тоску и скуку, которые А.С. Пушкин из просодических соображений часто использует как синонимы к хандре» (ibid).

Живой интерес к уникальному русскому роману сохраняется и в наше время. Свою версию романа в прозе предложил в 2005 году Р. Кларк, который стремился к тому, чтобы прежде всего передать его увлекательный сюжет, что потребовало адаптации текста для широкого круга читателей. Кроме того, известны переводческие работы Мэрилин Стоун (Marilyn K. Stone) 2005 года и Стенли Митчелла (Stanley Mitchell) 2008 года. Конечно, этими фамилиями история перевода романа «Евгений Онегин» на английский язык в XXI веке не исчерпывается: мы можем предположить, что кроме полностью законченных и опубликованных переводов романа существуют фрагменты текста на английском языке, которые размещены в Интернете их иностранными или российскими авторами, возможно, даже не профессиональными переводчиками.

Имея в виду энтузиазм англоязычных переводчиков романа в XX веке, а также реагирующих на него критиков, К.И. Чуковский, который сам был блистательным переводчиком, а потому и строгим критиком чужих переводов, писал: «Как ни отнестись к качеству этих переводов, нужно сказать, что каждый из них - результат многолетнего, большого труда. В дватри месяца "Онегина" стихами не переведешь: в нем 5540 рифмованных 
строк. Юджин Кейден сообщает в своем предисловии, что он работал над “Онегиным" двадцать лет. ...И замечательно, что англо-американская критика встречает каждого нового “Онегина" несметным количеством статей и рецензий, обсуждая азартно и шумно его верность великому подлиннику... Мне, русскому, радостно видеть, как близко принимают к сердцу заморские и заокеанские люди творение гениального моего соотечественника» (Чуковский 1988: 334).

\section{3. Переводы романа на французский язык}

Текстов романа на французском языке существует меньше, чем на английском; наиболее заметными переводчиками «Евгения Онегина» на французский язык были следующие: И.С. Тургенев и Л. Виардо (L. Viardot) (1863), П. Безо (Paul Béesau) (1868), Г. Перо (G. Pérot) (1902), Ж. Ширак (J. Chirac) (1951), М. Колен (M. Colin) (1980), Н. Минор (N. Minor) (1990), P. Легра (R. Legras) (1994), Ж.-Л. Бакес (J.-L. Backès) (1996), А. Маркович (A. Markowicz) (2005), Ф. Вутев (F. Voutev) (2012), Т. Попова-Бонналь (T. Popova-Bonnal) (2018).

Первой попыткой перевода «Евгений Онегина» на французский язык была совместная работа русского писателя И.С. Тургенева и французского писателя и публициста Л. Виардо. Этот труд представляет собой переложение сюжета романа в прозе (хотя авторы высоко ценили уникальную онегинскую строфу) и был опубликован в 12-м и 13-м томах журнала «La Revue nationale et étrangère» («Национальный и иностранный журнал») в 1863 году. Кроме этого, авторы снабдили перевод краткими комментариями к тексту и составили небольшое предисловие, в котором, по их собственным словам, не могли решить «Pouchkine imitant Byron est supérieur à Pouchkine imitant Shakspeare» [превосходит ли Пушкин, подражающий Байрону, Пушкина, подражающего Шекспиру] (Pouchkine. Eugène Onéguine. Tr. Tourgueniev et Viardot 1863); они также указали на его близость к творчеству широко известных немецких и английских поэтов и писателей (И. Гёте, Ф. Шиллера, У. Шекспира, В. Скотта).

У переводчиков не вызывал сомнения тот факт, что роман «passe généralement pour le chef-d'œuvre de son auteur» [в целом считается шедевром своего автора] (ibid), потому что «Le poème d'Onéguine se ressent de la diversité des lieux, des époques et des situations où furent composées les différentes parties de l'œuvre» [В поэме Онегина ощущается разнообразие мест, эпох и ситуаций, из которых составлены различные части произведения] (ibid). Из этой цитаты следует, что авторы перевода подчеркивают сложность его сюжета и панорамность композиции: это неудивительно, ведь перевод был выполнен в 1863 году, когда события первой половины XIX века были еще живыми и актуальными для читателя второй половины XIX века.

Интересно, что в некоторых переводах отдельные строфы романа вовсе отсутствуют, о чем в 1881 году писал Г. Сполдинг, который не обнаружил ряда строф в немецких и французских переводах, возможно, в силу 
сложности для переводчика оригинального текста. Таким образом, «версия» романа И.С. Тургенева и Л. Виардо, несмотря на присущие ей недостатки, стала первой попыткой познакомить французского читателя с романом А.С. Пушкина, однако не смогла передать национальной уникальности и очарования оригинала.

Следующую попытку перевода «Евгения Онегина» на французский язык в 1868 году предпринял Поль Безо (Paul Béesau). Эта версия пушкинского текста также была сделана в прозе, и основной целью автора было знакомство французской публики с русским писателем: «“Eugène Onéguine”, regardé comme le chef-d'œuvre de Pouchkine, n'avait pas encore été traduit en notre langue» [“Евгений Онегин”, считающийся шедевром творчества Пушкина, еще не переводился на наш язык] (Pouchkine. Eugène Onéguine. Tr. Béesau 1868). Мы не нашли подтверждения того, что П. Безо был знаком с переводом И. Тургенева и Л. Виардо.

Оценивая роман с точки зрения стиля и содержания, П. Безо отмечает, что в нем нет недостатка «ne manque ni d'originalité, ni de verve satirique, ni de douce poésie, sans parler des faits et gestes d'Onéguine» [ни в оригинальности, ни в блестящей сатире, ни в нежности поэзии, не говоря уже о поступках Онегина] (ibid). Главной же ценностью произведения он считает «une galerie de tableaux pris çà et là dans l'existence russe et servant de fond à une action très-simple» [галерею картин, взятых из русской жизни и выполняющих функцию фона для развития очень простого действия] (ibid). Эта «простота» и очаровывает П. Безо, который призывает французского читателя XIX века прочесть роман: «Je n'ajoute plus un mot, et je confie à ceux qui savent encore goûter les choses simples et vraies le soin de statuer sur le sort d'Onéguine» [Я не добавлю более ни слова и доверяю тем, кто еще умеет получать удовольствие от простых и правдивых вещей, самим судить о судьбе Онегина] (ibid).

Это небольшое по объему предисловие особенно интересно с точки зрения открытого выражения позиции переводчика, который, оценив «нежную поэзию», призывает французского читателя получить удовольствие от разнообразия характеров, простоты сюжета и галереи картин русской жизни. Внимание П. Безо к тому, чтобы точно передать черты национального быта, обнаруживается в деталях. Используя, как и другие переводчики, транслитерацию национально-культурной лексики, он пишет слово Samovar с большой буквы («Шипел вечерний самовар» Глава III, строфа XXXVII) и сохраняет в транслитерации слово возок (vosok). В то же время И.С. Тургенев переводит его как voiture à patins («средство передвижения на полозьях»), а Ч. Джонстон - как sledded coach («сани»), что конкретизирует семантику слова, позволяя читателю наглядно представить способ передвижения в условиях русской зимы («возок»- зимний крытый экипаж на полозьях).

Отметим, что сопоставительный характер переводов еще раз подчеркивает не теряющую своей актуальности проблему передачи на другой язык национально-культурной лексики: выбор между транслитерацией 
и собственно переводом всегда является личным выбором переводчика, что и показывает анализ выделенных «русизмов» (см. стр. 9). Перевод П. Безо, опубликованный спустя всего 30 лет после гибели поэта, занял свое место в хронологии франкоязычных версий «Евгения Онегина», потому что он был вторым и, возможно, последним в рамках XIX века французским переводом романа.

Среди переводов романа на французский язык XX века многих авторов (Г. Перо (1902), Ж. Ширак (1951), М. Колен (1980), Н. Минор (1990), Р. Легра (1994), Ж.-Л. Бакес (1996)) известный филолог, историк литературы и переводчик Е.Г. Эткинд выделяет переводы Гастона Перо и Мориса Колена: «Особый интерес представляют переводы “Евгения Онегина"; среди нескольких переводов (главным образом прозаических) выделяются два, исполненные строфой оригинала: Гастона Перо (1902) и Мориса Колена (1980)» [Эткинд 1999: 16].

Один из переводов XX века был сделан будущим Президентом Французской Республики Жаком Шираком. Канадский франкоязычный телевизионный канал TVA nouvelles 30 июня 2001 года опубликовал на своем интернетпортале заметку под названием «Жак Ширак - переводчик Пушкина» (Jacques Chirac traducteur de Pouchkine) ${ }^{5}$. В этой публикации содержался анонс интервью с Жаком Шираком, где он рассказал, что в двадцатилетнем возрасте, находясь «под большим впечатлением от Пушкина», он по заданию своего преподавателя русского языка перевел роман А.С. Пушкина «Евгений Онегин». Однако ни одно издательство не согласилось опубликовать перевод: «Probablement n'était-elle pas assez bonne» (Вероятно, он [перевод] был недостаточно хорош), - предположил сам Ж. Ширак. Этим, вероятно, объясняется тот факт, что нам не удалось обнаружить текст этого перевода.

Обратимся к переводу XXI века (2005 года), предложенному Андре Марковичем, который имел безусловный успех у французского читателя. Это объясняется тем, что перевод был сделан в стихотворной форме: в нем автор предпринимает попытку повторить онегинскую строфу, чтобы передать французскому читателю секрет легкости пушкинского стиха, что облегчило бы восприятие содержания романа. В своей работе А. Маркович уделяет внимание деталям, ироническому тону повествования, придавая этому не меньшее значение, чем точности изложения. Переводу предшествует предисловие, в котором автор изящно и точно характеризирует то содержание романа, которое определяется личностью каждого из молодых героев. «À travers ses strophes d'octosyllabes, simples, ironiques et lyriques, Pouchkine raconte l'histoire de ces jeunes coeurs bercés d'ennui et de rêves: le spleen d'Onéguine, le tourment de Tatiana, la flamme de Lenski et la naïveté d'Olga. La mélancolie, le romantisme, l'ironie et le drame se conjuguent jusqu'au duel fratricide et aux amours perdues» [В своих простых, ироничных и лиричных

${ }^{5}$ URL: https://www.tvanouvelles.ca/2001/06/30/jacques-chirac-traducteur-de-pouchkine (дата обращения: 15 сентября 2020) 
восьмистопных строфах Пушкин рассказывает историю молодых сердец, взращенных в тоске и мечтах: сплин Онегина, мучения Татьяны, пламенность Ленского и наивность Ольги. Меланхолия, романтизм, ирония и драма сплетаются в братоубийственной дуэли и потерянной любви] (Pouchkine. Eugène Onéguine. Tr. Markowicz 2005).

Поэтическая оценка пушкинского текста А. Марковичем свидетельствует о том, что он уловил дух романа, не только почувствовал лиризм сюжета и формы, но и постарался передать иронический подтекст авторских отступлений. Именно поэтому данный перевод до сих пор принято считать одним из лучших и близким к оригинальному тексту. Создается впечатление, что А. Маркович, в отличие от И.С. Тургенева и П. Безо, не считал своей основной задачей адаптацию оригинального текста.

Упомянем также переводы Роже Легра (R. Legras, 1994), Татьяны Поповой-Бонналь (T. Popova-Bonnal, 2018) и Флориана Вутева (F. Voutev, 2012). В переводе Р. Легра можно отметить стремление передать авторскую иронию; Т. Попова-Бонналь сопровождает перевод короткими комментариями, которые помогают зарубежному читателю лучше понять текст, познакомиться с жизнью русского человека, больше узнать о «загадочной» русской душе и русской культуре. Так, например, у нее есть замечания о личности самого А.С. Пушкина, иронический тон которых соответствует иронии оригинального текста: «...car Pouchkine ne rate jamais bonnes femmes! Il n'aime que la jeune fille discrète et romantique» [...так как Пушкин никогда не пропускал красивых женщин! Ему нравятся только скромные и романтические девушки] (Pouchkine. Eugène Onéguine. Tr. Popova-Bonnal 2018). Кроме того, переводчик делает грамматические пометы по поводу отдельных слов: «L'hiver est féminin en russe» [Зима в русском языке женского рода] (ibid).

Работа над текстом А.С. Пушкина заняла у Ф. Вутева почти четыре года и стала для него дебютом в области литературного перевода. Он замечает, что ему «было интересно узнать, как звучит он [роман] на языке Расина и Верлена» ${ }^{6}$, «любопытство мое было чисто читательское. Признаюсь, кстати, я ни одного из этих переводов не дочитал до конца. Я даже постарался вполне их забыть, когда неожиданно для себя начал переводить роман. В противном случае получилось бы какое-то подражание или неудачная переработка чужих переводов» (ibid). Стремление испытать свои силы в переводе романа побудило его перевести примечания А.С. Пушкина к роману и попытаться воспроизвести онегинскую строфу.

Завершая обзор французских переводов, отметим, что приведенные выше слова К.И. Чуковского «Мне, русскому, радостно видеть, как близко принимают к сердцу заморские и заокеанские люди творение гениального моего соотечественника» (Чуковский 1988: 334) в полной мере можно отнести и к переводам романа на французский язык. Однако проанализированный

${ }^{6}$ URL: http://rusoch.fr/ru/guests/novyj-francuzskij-onegin.html 
материал не показывает такого явного пристрастного отношения французских переводчиков к деятельности своих коллег, как среди англоязычных переводчиков.

\section{3. Заключение}

Художественные ценности высокой культуры, которые еще вчера казались незыблемыми, сегодня перестают быть одним из главных объектов научного описания. В современной лингвистике «абстрактно-гуманитарные интересы заменяются утилитарно-профессиональными, а язык распространяется через туризм, экономику и науку, что реально дает возможность функционировать русскому языку как мировому» (Протасова 2013).

С таким мнением, которое сегодня широко высказывается в связи с тенденцией к изучению и описанию любого языка в аспекте коммодификации, то есть в сугубо прагматических целях (медицина, бизнес, туризм, и др.), трудно не согласиться ${ }^{7}$. Этому способствуют и общие процессы глобализации и цифровизации, которые проявляются в частности в изучении новых типов текстов, например, мультимодальных. Эта эволюция самого языка и науки о нем вполне закономерна, однако «абстрактно-гуманитарные интересы», несмотря ни на что, остаются важной частью межкультурной коммуникации, о чем свидетельствует неиссякаемый интерес к национальным литературным шедеврам, который обусловливает появление все новых и новых переводов произведений художественной литературы, в том числе - русской классики XIX века.

Переводы романа «Евгений Онегин», сделанные в конце XX и начале XXI веков, позволяют говорить о том, что сложность самой задачи, скорее, способствует стремлению переводчиков новых поколений покорить эту художественную вершину. Не случайно переводческая деятельность на протяжении почти двух веков сопровождается профессиональными дискуссиями, которые находят отражение в предисловиях и комментариях авторовпереводчиков. В них же часто отражается и общая неудовлетворенность последних результатами своего труда: поставленная задача оказывается не решенной в полной мере - выбор между формой и содержанием или попытка найти компромисс между ними не дает желаемого эффекта.

«Многоголосие» переводчиков романа, которое нам удалось «услышать» благодаря тому, что переводы были рассмотрены в хронологической последовательности, а также проанализированы комментарии к ним, свидетельствует о существовании прочной традиции, сложившейся в европейском переводоведении именно вокруг этого произведения. Эта традиция не прерывается и в XXI веке - можно выразить уверенность в том, что не прервется и в дальнейшем. Пушкинский гений, до сих пор в полной мере не

${ }^{7}$ См. об этом подробно: Muth 2017, а также весь спецвыпуск журнала Russian Journal of Linguistics 23 (3) 2017, полностью посвященный проблеме коммодификации русского языка. 
понятый в Европе, остается притягательным не только для русскоязычных переводчиков (такие переводы также продолжают появляться, однако они остались за рамками нашей статьи), но и для носителей других языков.

Как показал проделанный анализ, трудно преодолимым препятствием для переводчиков является музыкальность пушкинского стиха и особое положение четырехстопного ямба в русской поэзии XIX века в целом, а также «шифр» онегинской строфы, в частности. Видимая простота сюжета оказывается обманчивой, так как восполняется широкой панорамностью лирических отступлений. Кроме того, высокая степень историзма (наличие в тексте архаизмов, старославянизмов, заимствований, народной и разговорной лексики) создает особые трудности при переводе. Общие стилистические регистры речи русского языка, с одной стороны, английского и французского языков - с другой, не совпадают, что затрудняет саму возможность передать национальное своеобразие эпохи первой трети XIX века, нюансы пушкинской иронии.

Bсе эти уникальные особенности пушкинского текста метафорически соединены в поэтически точном оксюмороне А.А. Ахматовой, которая назвала роман «воздушной громадой» (И было сердиу ничего не надо, / Когда пила я этот жгучий зной... / «Онегина» воздушная громада, / Как облако, стояло надо мной). Образ облака передает ощущение погружения читателя в этот роман: переводчик, который одновременно является и адресатом текста оригинала, и адресантом переводного текста, «входит в это облако», увлекая за собой иноязычного читателя сегодня так же, как и сто пятьдесят лет назад.

Независимо от результата каждая попытка перевода пушкинского романа на любой иностранный язык вносит существенный вклад в развитие межкультурной коммуникации. Однако отметим, что переводы романа на английский и французский языки особенно актуальны, так как напоминают о том, что «Евгений Онегин» является фактом не только русской, но и европейской культуры a priori, поскольку его автор был русским человеком европейской культуры своего времени.

Таким образом, даже в современных условиях «утилитарно-профессиональной ориентации» истинные ценности высокой культуры продолжают занимать важное место в межкультурной коммуникации - в том числе и как объект научного описания.

(C) Elena Remchukova and Ekaterina Nedopekina, 2020

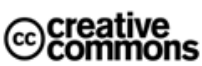

This work is licensed under a Creative Commons Attribution 4.0 International License https://creativecommons.org/licenses/by/4.0/

\section{СПИСОК ЛИТЕРАТУРЫ / REFERENCES}

Богинская А.П. К проблеме анализа параллельных текстов: четыре французских перевода «Евгения Онегина» // Ученые записки Орловского государственного 
университета. 2016. № 3 (72). С. 138-145. [Boginskaya, Anastasiya P. 2010. K probleme analiza parallel'nykh tekstov: chetyre frantsuzskikh perevoda «Evgeniya Onegina» (To the problem of analyzing parallel texts: four French translations of "Eugene Onegin"). Uchenye zapiski Orlovskogo gosudarstvennogo universiteta 3 (72). 138-145].

Бодров В.А. Постижение Пушкина (Владимир Набоков) [Электронный ресурс] // Современные проблемы науки и образования. 2006. № 3. http://www.science-education.ru/ ru/article/view?id=310 (дата обращения: 13.07.2020). [Bodrov, Vladimir A. 2006. Postizhenie Pushkina (Vladimir Nabokov) (Comprehension of Pushkin (Vladimir Nabokov). Sovremennye problemy nauki $i$ obrazovaniya, 3, http:/www.scienceeducation.ru/ru/article/view?id=310 (accessed 13 July, 2020)].

Виноградов В.В. Стиль Пушкина. М.: Наука. 1999. 704 с. [Vinogradov, Victor V. 1999. Stil' Pushkina (Pushkin's style). Moscow: Nauka].

Гак В.Г. Язык Пушкина и французский язык // Вопросы языкознания. 2000. № 2. C. 7-89. [Gak, Vladimir G. 2000. Yazyk Pushkina i frantsuzskii yazyk (Pushkin's language and French language). Voprosy yazykoznaniya 2. 79-89].

Лотман Ю.М. Роман А.С.Пушкина «Евгений Онегин»: Комментарий. Пособие для учителя. Л.: Просвещение, 1983. 416 с. [Lotman, Yurii M. 1983. Roman A.S. Pushkina «Evgenii Onegin»: Kommentarii. Posobie dlya uchitelya (Alexander Pushkin's novel "Eugene Onegin": Commentary. Teacher's manual). Leningrad: Prosveshchenie].

Набоков В.В. Комментарий к роману А.С. Пушкина «Евгений Онегин» (пер. Н. Жутовской). Санкт-Петербург: Искусство, 1999. 928 с. [Nabokov, Vladimir V. 1999. Kommentarii k romanu A.S. Pushkina «Evgenii Onegin» (Commentary on the novel by A.S. Pushkin "Eugene Onegin”). Saint Petersburg: Iskusstvo].

Нестерова Н.M. «С живой картины список бледный»: об английских переводах «Евгения Онегина» А.С. Пушкина [Электронный ресурс] // Вестник Пермского федерального исследовательского иентра. 2014. № 4. С. 26-35. http://journal.permsc.ru/index.php/ pscj/article/view/PSCJ2014n4p4 (дата обращения: 24.10.2020). [Nesterova, Natal'ya M. 2014. "S zhivoi kartiny spisok blednyi": ob angliiskikh perevodakh "Evgeniya Onegina" A.S. Pushkina ("From a living picture the list is pale": about the English translations of Eugene Onegin by A.S. Pushkin). Vestnik Permskogo federal'nogo issledovatel'skogo tsentra 4. 26-35. http://journal.permsc.ru/index.php/pscj/article/view/PSCJ2014n4p4 (accessed 24 October, 2020].

Панченко Е.И. О некоторых лингвокультурологических особенностях перевода поэзии романа «Евгений Онегин». Видавництво ДНУ, 2011. [Panchenko, Elena I. 2011. O nekotorykh lingvokul'turologicheskikh osobennostyakh perevoda poezii romana «Evgenii Onegin» (On some linguistic and cultural features of the novel "Eugene Onegin" poetry translation). Vidavnitstvo DNU].

Плохотников Г.А. Концептуальные сложности художественной интерпретации в переводческой деятельности В. Набокова [Электронный ресурс] // Международный студенческий научный вестник. 2015. № 6. http://www.eduherald.ru/ru/article/ view?id=14272 (дата обращения: 13.07.2020). [Plokhotnikov, Gennadii, A. 2015. Kontseptual'nye slozhnosti khudozhestvennoi interpretatsii $\mathrm{v}$ perevodcheskoi deyatel'nosti V. Nabokova (On some linguistic and cultural features of the novel "Eugene Onegin" poetry translation). Mezhdunarodnyi studencheskii nauchnyi vestnik 6. http://www.eduherald.ru/ru/article/view?id=14272 (accessed 13 July, 2020].

Протасова Е. Русский язык в туристическом ландшафте зарубежья // Русский язык за рубежом. 2013. № 4. С. 53-61. [Protassova, Ekaterina 2013. Russkii yazyk v turisticheskom landshafte zarubezh'ya (Russian Language in Tourism Landscape Abroad). Russkii Yazyk za Rubezhom 5. 53-61]. 
Сдобников В.В. Переводоведение сегодня: вечные проблемы и новые вызовы // Вестник Российского университета дружбы народов. Серия: Лингвистика. 2019. Т. 23. № 2. C. 295-327. [Sdobnikov, Vadim V. 2019. Translation studies today: Old problems and new challenges. Russian Journal of Linguistics 23 (2). 295-327]. DOI: 10.22363/23129182-2019-23-2-295-327.

Чеснокова О.С., Талавера-Ибарра П.-Л. «Демон» М.Ю. Лермонтова: обратный перевод как источник интертекстуальности // Вестник РУДН. Серия: Лингвистика. 2015. № 2. C. 166-179. [Chesnokova, Olga S., Talavera-Ibarra, Pedro L. 2015. [«Demon» M.Yu. Lermontova: obratnyi perevod kak istochnik intertekstual'nosti ("Demon" by M.Yu. Lermontov: Reverse translation as a source of intertextuality). Russian Journal of Linguistics 2. 166-179].

Челышев Е.П. Из истории постижения смыслов пушкинского текста: проблемы языка, понимания и культуры перевода [Электронный ресурс] // Электронное научное издание Альманах Пространство и Время. 2015. Т. 10, вып. 1: Пространство и время текста. http://j-spacetime.com/actual\%20content/t10v1/2227-9490e-aprovr e-ast10-1.2015.61.php. (дата обращения: 15.10.2020). [Chelyshev, E. 2015. Iz istorii postizheniya smyslov pushkinskogo teksta: problemy yazyka, ponimaniya i kul'tury perevoda. Elektronnoe nauchnoe izdanie Al'manakh Prostranstvo $i$ Vremya 10 (1): Prostranstvo i vremya teksta. http://j-spacetime.com/actual\%20content/t10v1/22279490e-aprovr_e-ast10-1.2015.61.php. (accessed 15 October, 2020)].

Чуковский К.И. Искусство перевода. М.; Л.: Academia, 1936. 222 с. [Chukovskii, Kornei I. 1936. Iskusstvo perevoda (The art of translation). Moskaw; Leningrad: Academia.].

Чуковский К.И. Онегин на чужбине // Дружба народов. 1988. № 4. С. 324. [Chukovskii, Kornei I. 1988. Onegin na chuzhbine (Onegin in a foreign land). Druzhba narodov 4. 324].

Эткинд Е.Г. Поэзия А.С. Пушкина во французских переводах // Пушкин, А.С. Избранная поэзия в переводах на французский язык / сост. Е.Г. Эткинд; авт. вступ. ст. Е.Г. Эткинд. Москва: Рудомино: Радуга, 1999. С. 5-22. [Etkind, Efim G. 1999. A.S. Pushkin's Poetry in French Translation». In A.S. Pushkin. Selected Poetry in French Translation. 5-22. Moscow: Rudomino Publisher; Raduga Publisher].

Behr, Dorothée \& Mandy Sha. 2018. Translation of questionnaires in cross-national and crosscultural research. Translation and Interpreting 10 (2). 5-20.

Buden, Boris, Stefan Nowotny, Sherry Simon, Ashok Bery \& Michael Cronin. 2009. Cultural translation: An introduction to the problem, and Responses. Translation Issues 2 (2). 196-219. DOI: 10.1080/14781700902937730.

Dam-Jensen, Helle, Carmen Heine \& Iris Schrijver. 2020. The Nature of Text Production Similarities and Differences between Writing and Translation. Across Languages and Cultures 20 (2). 155-172. DOI: 10.1556/084.2019.20.2.1

Danilova, Vasilisa. 2020. Ways of conveying ethnocultural lexicon in translation of the novel Eugene Onegin by A.S. Pushin into Portuguese (on the materials of Dário Moreira de Castro Alves' translation). Litera 7. 100-108. DOI: 10.25136/2409-8698.2020.5.32880.

Dmitrieva, Elena. 1999. «Un Bilingue parfait: Pouchkine et la langue française». Langues étrangères à l'école 3. 79-84. Moscou.

Kobrina-Coolidge, Julia. 2015. Vladimir Nabokov as a Translator of Pushkin's Novel in Verse "Eugene Onegin". https://www.academia.edu/34593086/Vladimir_Nabokov_as_a_ Translator_of_Pushkins_Novel_in_Verse_Eugene_Onegin (accessed 20 October, 2020).

Loupaki, Elpida. $\overline{2017}$. Multilinguisme, multiculturalisme et pratique traduisante au sein de l'Union européenne. The Journal of Specialised Translation 28. 52-68.

Muth, Sebastian. 2017. Russian language abroad: Viewing language through the lens of commodification. Russian Journal of Linguistics 23(3), 463-492. 
Nesterova, Natal'ya M. \& Yuliya Popova K. 2017. Eugene Onegin in the English-speaking Linguacultural Space. Rupkatha Journal on Interdisciplinary Studies in Humanities 9 (4). $82-101$.

Perdikaki, Katerina. 2018. Film adaptation as the interface between creative translation and cultural transformation: The case of Baz Luhrmann's The Great Gatsby. The Journal of Specialised Translation 29. 169-188.

Razumnaya, Anna. 2012. Onegin in English: Against Nabokov. Literary Imagination 14 (3). 277-291. https://doi.org/10.1093/litimag/ims064.

Razumovskaya, Veronica A. 2011. Mystical scenes in the novel Eugene Onegin: reconstruction in translations. Journal of Siberian Federal University. Humanities \& Social Sciences 10. 1432-1443.

\section{Текст и переводы романа А.С. Пушкина «Евгений Онегин»}

Пушкин А.С. Полное собрание сочинений: в 10 т. АН СССР. Институт русской литературы (Пушкинский Дом); Т. 5. Евгений Онегин. Драматические произведения (Eugene Onegin. Dramatic works). Ленинград: Наука. Ленинградское отделение, 1978, 529 c. [Pushkin, Aleksander S. 1978. Polnoe sobranie sochinenii: V10 t. AN SSSR. Institut russkoi literatury (Pushkinskii Dom), 5. Evgenii Onegin. Dramaticheskie proizvedeniya. Leningrad: Nauka. Leningradskoe otdelenie].

Pushkin, Alexander. 1977. Eugene Onegin. Translated by Charles H. Johnston, Hannondsworth: Penguin Books Ltd.

Pouchkine, Alexandre. 2005. (trad. André Markowicz, préf. Michaël Meylac, postface André Markowicz), Eugène Onéguine (roman en vers), Arles, Actes Sud, coll. «Babel» (n 924), 2005 (1re éd. 2005), 380 p. [Pushkin, Alexander. 2005. Eugene Onegin. Trans. Andrei Markovich, pref. Michael Meylac, postface Andrei Markovich. 380].

Pouchkine, Alexandre. Eugène Onéguine (Roman en vers). Nouvelle traduction de Florian Voutev, LA BRUYERE, 2012, 239 p. [Pushkin, Alexander. 2012. Eugene Onegin. Trans. Florian Voutev. 239].

Pouchkine, Alexandre. Eugène Onéguine Traduction d'Ivan Tourgueniev et Louis Viardot in la Revue nationale et etrangere, t. 12 \& 13, 1863. [Pushkin, Alexander. 1863. Eugene Onegin. Trans. Louis Viardot. Revue nationale et Etrangere].

Pouchkine, Alexandre. Eugène Onéguine. Trad. Roger Legras, Lausanne, Editions l'Âge d'Homme, 1994, 120 p. [Pushkin, Alexander. 1994. Eugene Onegin. Trans. Roger Legras. 120].

Pouchkine, Alexandre. Eugène Onéguine. Traduction par Paul Béesau, Librairie A. Franck, 1868. [Pushkin, Alexander. 1868. Eugene Onegin. Trans. Paul Beesau, Librairie Franck Launai].

Pouchkine, Alexandre. Eugène Onéguine: Traduction: Tetyana Popova-Bonnal. Kindle Edition, 2018, 225 p. [Pushkin, Alexander. 2018. Eugene Onegin. Trans. Tetyana PopovaBonnal. Kindle Edition. 225].

Eugene Onegin: A Romance of Russian Life in Verse by Alexander Pushkin. Translated from the Russian by Lieut.- Col. [Henry] Spalding, London: Macmillan and Co., 1881.

Eugene Onegin, a novel in verse by Alexander Pushkin; a new translation by Babette Deutsch [1895-1982]; edited, with a special introduction, by Avrahm Yarmolinsky; illustrated with lithographs by Fritz Eichenberg, New York: Heritage Press 1943. LCCN (Library of Congress Control Number): 43012373. 
Article history:

Received: 17 August 2020

Revised: 25 October 2020

Accepted: 27 October 2020

История статьи:

Дата поступления в редакцию: 17 августа 2020

Дата принятия к печати: 27 октября 2020

\section{Bionotes:}

Elena N. REMCHUKOVA is Professor at the Department of General and Russian Linguistics, the Faculty of Philology, Peoples' Friendship University of Russia (RUDN University). She is a member of the editorial committee of the research journal Tsennosti $i$ Smysly (Values and Senses) and a reviewer of the research journal Cuadernos de Rusistica Española (WoS).

\section{Contact information:}

Peoples' Friendship University of Russia (RUDN University), 6 Mikluho-Maklaya str., Moscow, 117198, Russia.

e-mail: remchukova-en@rudn.ru

ORCID ID: 0000-0002-7901-9622

Ekaterina M. NEDOPEKINA holds a PhD in Philology and Slavic Studies (Russia and France). She is an Associate Professor at the Department of General and Russian Linguistics, the Faculty of Philology, Peoples' Friendship University of Russia (RUDN University). Ekaterina is the coordinator of the RUDN University activities at the RussianFrench Network University and the coordinator of the Master program Russia-Europe languages and cultures (jointly with the University of Bordeaux Montaigne, France).

\section{Contact information:}

Peoples' Friendship University of Russia (RUDN University), 6 Mikluho-Maklaya str., Moscow, 117198, Russia.

e-mail: nedopekina-em@rudn.ru

ORCID ID: 0000-0002-5922-3669

\section{Сведения об авторах:}

Елена Николаевна РЕМЧУКОВА - профессор кафедры общего и русского языкознания филологического факультета Российского университета дружбы народов (РУДН), доктор филологических наук, член редакционного комитета научного журнала «Ценности и смыслы», рецензент научного журнала Cuadernos de Rusística Española (WoS).

\section{Контактная информация:}

Российский университет дружбы народов (РУДН), ул. Миклухо-Маклая, д. 6, Москва, 117198, Россия

e-mail: remchukova-en@rudn.ru

ORCID ID: 0000-0002-7901-9622 
Екатерина Михайловна НЕДОПЁКИНА - доцент кафедры общего и русского языкознания филологического факультета Российского университета дружбы народов, $\mathrm{PhD}$ филология и славяноведение (Россия и Франция), координатор деятельности РУДН в Российско-французском сетевом университете, координатор магистерской программы «Россия-Европа: языки и культуры», реализуемой совместно с Университетом Бордо Монтень, Франция.

Контактная информация:

Российский университет дружбы народов (РУДН), ул. Миклухо-Маклая, д. 6, Москва, 117198, Россия

e-mail: nedopekina-em@rudn.ru

ORCID ID: 0000-0002-5922-3669 